\title{
Insiden Hiponatremia Pasca operasi Mayor pada Anak di Ruang Rawat Intensif
}

\author{
Nathanne Septhiandi, Rismala Dewi, Piprim B. Yanuarso, Evita Kariani B. Ifran, Novie Amelia, Eka Laksmi Hidayati \\ Departemen Ilmu Kesehatan Anak Fakultas Kedokteran Universitas Indonesia/RS Cipto Mangunkusumo, Jakarta
}

\begin{abstract}
Latar belakang. Penggunaan cairan yang tidak tepat sering menimbulkan peningkatan kejadian hiponatremia yang berhubungan erat dengan meningkatnya berbagai komplikasi, seperti edema otak, kejang, bahkan kematian.

Tujuan. Mengetahui insiden hiponatremia pada anak pasca tindakan operasi mayor.

Metode. Studi retrospektif potong lintang dilakukan terhadap anak usia 1 bulan hingga 18 tahun yang menjalani tindakan operasi mayor dan masuk ruang rawat intensif. Penelusuran status medik sesuai kriteria inklusi dilakukan sampai jumlah sampel terpenuhi. Dicatat data subjek pre operasi, intra operasi, serta pemantauan pasca operasi. Definisi hiponatremia $<135 \mathrm{mEq} / \mathrm{L}$, diklasifikasikan sesuai derajat hiponatremia dan dilakukan pencarian lebih lanjut terhadap komplikasi.

Hasil. Didapat 90 subjek, terdiri atas 56,7\% laki-laki $(51,1 \%)$ dan rentang usia 1 bulan hingga 17 tahun. Tindakan laparatomi dengan berbagai indikasi dijalani 47,8\% subjek. Hampir semua subjek (9 3,3\%) mendapat cairan hipotonik pasca operasi. Insiden hiponatremia pasca operasi $28,9 \%, 11,1 \%$ di antaranya hiponatremia sedang-berat. Rerata kadar natrium pasca operasi $(130,1 \pm 4,1) \mathrm{mEq} / \mathrm{L}$, rerata total cairan $(79,8 \pm 27,4) \mathrm{mL} / \mathrm{kg}$. Pada 30,9\% subjek yang mendapatkan cairan hipotonik pasca operasi

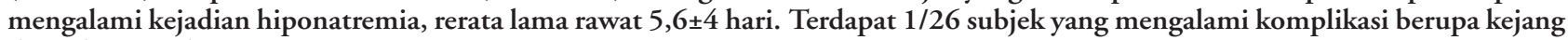
dan edema otak.

Kesimpulan. Insiden hiponatremia pasca tindakan operasi mayor di ruang rawat intensif hampir mencapai $30 \%$ dan sebagian besar mendapat cairan hipotonik pasca operasi. Penelitian lebih lanjut perlu dilakukan untuk mengevaluasi pemberian cairan pasca operasi yang tepat untuk mencegah hiponatremia. Sari Pediatri 2016;17(5):327-34.
\end{abstract}

Kata kunci: hiponatremia, pasca operasi, anak, ruang perawatan intensif

\section{Incidence of Postoperative Hyponatremia in Pediatric Intensive Care Unit}

Nathanne Septhiandi, Rismala Dewi, Piprim B Yanuarso, , Evita Kariani B. Ifran, Novie Amelia, Eka Laksmi Hidayati

Background. The use of improper fluid often leads to increasing incidence of hyponatremia which causes complications such as cerebral edema, seizure, and death.

Objective. To describe the incidence of hyponatremia in children after major surgery.

Methods. A retrospective cross-sectional study was conducted on children aged 1 month to 18 years who underwent major surgery and entered the intensive care ward. The inclusion subjects was traced from medical records. The data was recorded from preoperative, intraoperative, and postoperative monitoring. Subjects who met hyponatremia $(<135 \mathrm{mEq} / \mathrm{L})$ were classified according to the severity of hyponatremia and its complications.

Results. Ninety subjects were enrolled in this study (56.7\% male, $51.1 \%$ age 1 month-4 years). There were $47.8 \%$ subjects underwent laparotomy with a variety of indications. Almost all subjects (93.3\%) received postoperative hypotonic fluid. The incidence of postoperative hyponatremia was $28.9 \%$, while $11.1 \%$ among them were moderate-severe hyponatremia. The mean postoperative sodium levels was $130.1 \pm 4.1 \mathrm{mEq} / \mathrm{L}$ with a mean total fluid $79.8 \pm 27.4 \mathrm{ml} / \mathrm{kg}$. There were $30.9 \%$ subjects who received hypotonic fluids and experienced hyponatremia with a mean length of stay $5.6 \pm 4$ days. One of 26 subjects with hyponatremia suffered from seizures and brain edema.

Conclusions. The incidence of postoperative hyponatremia in pediatric intensive care reached nearly $30 \%$, and almost all of them received hypotonic fluid. Therefore, further research should be performed to evaluate the appropriate fluid in order to anticipating postoperative hyponatremia. Sari Pediatri 2016;17(5):327-34.

Keywords: hyponatremia, postoperative, children, intensive care

\footnotetext{
Alamat korespondensi: Dr. Nathanne Septhiandi. Departemen Ilmu Kesehatan Anak Fakultas Kedokteran Universitas Indonesia/RS Cipto Mangunkusumo, Jakarta. E-mail: $\underline{d}$ r.nathanne@gmail.com
} 
$\mathrm{H}$ iponatremia pasca tindakan operasi merupakan gangguan elektrolit yang sering terjadi pada populasi anak yang menjalani tindakan operasi. ${ }^{1-4}$ Studi kohort prospektif yang melibatkan 81 pasien pasca operasi menunjukkan insiden hiponatremia yang cukup tinggi dan progresif pada anak-anak yang dirawat di ruang perawatan intensif pasca tindakan operasi, yaitu sebesar $21 \%$ dalam 12 jam pertama dan $31 \%$ pada 24 jam pertama. ${ }^{1}$ Penelitian lain pada anak pasca tindakan operasi elektif di Kanada ditunjukkan terjadinya hiponatremia pasca operasi $23 \%-40 \% .^{2}$

Hipovolemia yang tidak disadari, pemberian cairan hipotonik saat operasi, kehilangan natrium, cerebral salt wasting, sekresi arginin vasopresin, redistribusi air ekstrasel, perubahan homeostasis sel pasca operasi dan peningkatan sekresi hormon antidiuretik (HAD) merupakan penyebab potensial dari hiponatremia. ${ }^{5,6}$ Sekresi HAD dipengaruhi oleh stimulus osmotik dan non osmotik yang bekerja melalui osmoreseptor dan baroreseptor. Stimulus osmotik yang berperan penting dalam sekresi HAD adalah osmolalitas plasma, terutama dipengaruhi oleh konsentrasi ion natrium dalam cairan ekstraselular. ${ }^{4,7,8}$ Sebaliknya, stimulus non osmotik utama yang berperan dalam sekresi HAD adalah hipovolemia dan hipotensi. Berbagai kondisi pasca operasi juga dapat menstimulasi sekresi HAD, seperti nyeri, stres, mual, anestesia, penggunaan ventilator mekanik, dan hipoksia. ${ }^{4,8,9}$

Peningkatan kejadian hiponatremia pasca operasi karena penggunaan cairan yang belum tepat, padahal kondisi ini berhubungan erat dengan meningkatnya berbagai komplikasi, seperti edema otak, kejang, bahkan kematian pada pasien rawat inap. ${ }^{3-5}$ Bila hiponatremia tidak terdeteksi, dapat menyebabkan gangguan neurologis permanen dan kematian. Populasi anak berisiko tinggi terjadinya hiponatremia simtomatik karena perbandingan antara jaringan otak dan tulang tengkorak pada anak lebih besar dibandingkan orang dewasa sehingga ruang yang tersedia saat terjadi edema otak lebih sempit. ${ }^{3-6}$

Hingga saat ini, cairan hipotonik (kadar natrium $<130 \mathrm{mEq} / \mathrm{L})$ masih kerap menjadi cairan pilihan pada pasien sakit kritis termasuk pasien pasca operasi. Penggunaan cairan hipotonik pasca operasi dapat memicu terjadinya hiponatremia. Perdebatan mengenai regimen pemberian cairan yang paling tepat masih terus terjadi. Kepustakaan bedah masih mendukung pemberian cairan hipotonik. ${ }^{10}$ Pada keadaan pasca operasi, survei mengenai pemilihan cairan hipotonik menunjukkan angka yang masih tinggi. Survei tahun 2004 terhadap 203 dokter spesialis anastesi di Inggris yang menangani pasien anak menunjukkan angka 87,4\%, tahun 2009 pada 472 residen anak di Amerika serikat $91,3 \%$ serta $69,2 \%$ pada 91 residen anak di Korea tahun 2013. ${ }^{11-13}$ Di sisi lain, kepustakaan lain merekomendasikan pemberian cairan isotonik (kadar natrium 130 - $154 \mathrm{mEq} / \mathrm{L}) .{ }^{4}$ Penggunaan cairan isotonik telah banyak direkomendasikan dalam beberapa kepustakaan terkini, bahkan di Inggris sejak tahun 2007 tidak diperbolehkan menggunakan cairan hipotonik di ruang rawat biasa. ${ }^{14-18}$ Pemberian cairan isotonik lebih disarankan pada saat intraoperasi dan periode awal pada saat pasien tidak dapat menoleransi asupan oral. ${ }^{19,20}$ Namun, evaluasi menyeluruh terhadap insiden hiponatremia masih jarang dilakukan dan pengaruh pemilihan jenis cairan terhadap komplikasi yang timbul serta efek yang tidak diinginkan dari terapi cairan seperti hipernatremia belum dapat digambarkan. Mengingat besarnya masalah yang dapat terjadi pada pasien dengan hiponatremia, banyak institusi yang mengukur kadar natrium sebagai pemeriksaan rutin berkala di ruang perawatan intensif anak meskipun tanpa ada indikasi.

Saat ini, tata laksana pemberian cairan di ruang perawatan intensif anak masih bersifat individual, masih menggunakan cairan hipotonik maupun isotonik. Pemeriksaan natrium juga belum menjadi pemeriksaan rutin berkala yang standar dilakukan. Meskipun hiponatremia cukup sering ditemukan pada pasien yang dirawat, belum banyak studi di Indonesia yang menginvestigasi secara spesifik mengenai hiponatremia di ruang perawatan intensif. Pada penelitian ini, diharapkan dapat memberikan data mengenai insiden hiponatremia pada anak pasca tindakan operasi yang dirawat di ruang perawatan intensif, karakteristik pasien, komplikasi dan juga stratifikasi berdasarkan tata laksana cairan pasca operasi yang digunakan.

\section{Metode}

Penelitian desain studi potong lintang secara retrospektif pada pasien anak usia 1 bulan hingga 18 tahun yang menjalani tindakan operasi mayor di ruang perawatan intensif Departemen Ilmu Kesehatan Anak FKUI Rumah Sakit Dr. Cipto Mangunkusumo, 
Jakarta. Waktu penelitian dimulai bulan JuniJuli 2015. Diikutsertakan pasien pasca operasi mayor yang memiliki kadar natrium preoperasi dan fungsi ginjal yang normal, data kadar natrium dalam 24 jam pasca operasi, dan mendapatkan cairan rumatan intravena minimal 6 jam dengan jumlah $\geq 70 \%$ dari kebutuhan cairan sesuai formula Holliday dan Segar. Kriteria penolakan adalah pasien yang menjalani operasi jantung, renal, bedah saraf, memiliki kelainan hipotiroid, sirosis hati, defisiensi glukokortikoid, gagal jantung dan mendapatkan medikasi yang dapat menyebabkan hiponatremia pada periode perioperatif.

Subjek penelitian diambil dari rekam medis sampai jumlah pasien terpenuhi. Penelusuran status medik pasien dengan kriteria penerimaan dilakukan secara retrospektif. Data yang dilakukan pencatatan meliputi identitas dasar, data preoperasi, data intraoperasi, serta pemantauan pasca operasi. Untuk setiap pasien yang memenuhi definisi hiponatremia, diklasifikasikan menjadi hiponatremia ringan, sedang, dan berat serta dilakukan pencarian lebih lanjut mengenai munculnya komplikasi terkait hiponatremia.

Insiden dari hiponatremia ringan, sedang, berat dan keseluruhan pada kelompok yang mendapatkan cairan isotonik dan hipotonik kemudian dihitung dan dibandingkan menggunakan perbandingan proporsi. Penelitian telah mendapatkan lolos kaji etik dari Komisi Etik Penelitian FKUI-RSCM dengan no. 495/ UN2.F1/ETIK/2015.

Tabel 1. Karakteristik subjek penelitian

\begin{tabular}{|c|c|c|c|}
\hline Karakteristik & Kategori & Jumlah $(\mathrm{n}=90)$ & Persentase (\%) \\
\hline \multirow[t]{5}{*}{ Usia } & 1 bulan -4 tahun & 46 & 51,1 \\
\hline & 5-8 tahun & 13 & 14,4 \\
\hline & $9-12$ tahun & 15 & 16,7 \\
\hline & 13-16 tahun & 15 & 16,7 \\
\hline & $>16$ tahun & 1 & 1,1 \\
\hline \multirow[t]{2}{*}{ Jenis kelamin } & Laki-laki & 51 & 56,7 \\
\hline & Perempuan & 39 & 43,3 \\
\hline \multirow[t]{14}{*}{ Tindakan bedah } & Laparatomi & 43 & 47,8 \\
\hline & Bone surgery & 20 & 22,3 \\
\hline & Torakotomi & 5 & 5,6 \\
\hline & Repair buli & 5 & 5,6 \\
\hline & Orkidektomi & 3 & 3,3 \\
\hline & Maksilektomi & 3 & 3,3 \\
\hline & Ekstraksi katarak & 2 & 2,2 \\
\hline & Parotidektomi & 2 & 2,2 \\
\hline & Artroplasti & 2 & 2,2 \\
\hline & Repair tumor clivus & 1 & 1,1 \\
\hline & Appendiktomi & 1 & 1,1 \\
\hline & Mastektomi & 1 & 1,1 \\
\hline & Supraglotoplasti & 1 & 1,1 \\
\hline & Adenoidektomi & 1 & 1,1 \\
\hline \multirow[t]{2}{*}{ Jenis cairan pasca operasi } & Hipotonik & 84 & 93,3 \\
\hline & Isotonik & 6 & 6,7 \\
\hline \multirow[t]{5}{*}{ Lama rawat (hari) } & $0-5$ & 64 & 71,1 \\
\hline & $6-10$ & 20 & 22,2 \\
\hline & $11-20$ & 6 & 6,7 \\
\hline & $21-30$ & 0 & 0 \\
\hline & $>31$ & 0 & 0 \\
\hline \multirow[t]{2}{*}{ Mortalitas } & $\mathrm{Ya}$ & 4 & 4,4 \\
\hline & Tidak & 86 & 95,6 \\
\hline
\end{tabular}




\section{Hasil}

Didapatkan 90 subjek yang diteliti, terdiri atas 56,7\% laki-laki dan 43,3\% perempuan dengan rentang usia dari 1 bulan hingga 17 tahun. Mayoritas rentang subjek adalah 1 bulan hingga 4 tahun dengan jumlah $51,1 \%$. Hampir separuh subjek menjalani tindakan laparatomi $(47,8 \%)$ dengan berbagai indikasi (reseksi tumor, transposisi kolon, adhesiolisis, prosedur Kasaii, pemasangan kolostomi, hingga reseksi anastomosis), diikuti oleh bone surgery $(22,3 \%)$ yang meliputi tindakan debridement, dekompresi, osteotomi, hip disartikulasi, stabilisasi, dan pemasangan minerva cast). Variasi durasi operasi subjek 1 hingga 14,5 jam dengan median 4,5 jam. Hampir semua (84 subjek, 93,3\%) subjek mendapatkan cairan hipotonik pasca operasi. Sebagian besar subjek dirawat selama 0-5 hari dengan kuantitas 68,9\% (62 subjek). Terdapat empat subjek yang mengalami luaran mortalitas, walaupun tidak ada yang terkait dengan hiponatremia.

Pascaoperasi didapatkan $26(38,9 \%)$ subjek yang mengalami hiponatremia, sebagian besar $(17,8 \%)$

Tabel 2.Kejadian hiponatremia

\begin{tabular}{lcc}
\hline Hiponatremia & Jumlah $(\mathrm{n}=90)$ & Persentase $(\%)$ \\
\hline Tidak hiponatremia & 64 & 71,1 \\
Ringan & 16 & 17,8 \\
Sedang & 8 & 8,9 \\
Berat & 2 & 2,2 \\
\hline
\end{tabular}

mengalami hiponatremia ringan. Delapan subjek mengalami hiponatremia sedang dan 2 subjek mengalami hiponatremia berat.

Berdasarkan jenis cairan yang diterima, pada subjek yang menerima cairan isotonik, tidak ada yang mengalami hiponatremia. Sementara itu,, pada subjek yang menerima cairan hipotonik didapatkan 26 mengalami hiponatremia dan 58 subjek tidak mengalami. Apabila dikelompokkan berdasarkan derajat hiponatremia yang ada, hampir $1 / 5$ subjek yang mendapatkan cairan hipotonik mengalami hiponatremia ringan $(19 \%)$, sedang $(9,5 \%)$, dan berat $(2,5 \%)$.

Komplikasi yang berkaitan dengan hiponatremia didapatkan 1 subjek mengalami kejang serta edema otak dengan kadar natrium $123 \mathrm{mEq} / \mathrm{L}$. Walaupun didapatkan 4 luaran dengan mortalitas dari 90 subjek, hal tersebut tidak berhubungan dengan hiponatremia. Tidak didapatkan subjek yang mengalami komplikasi edema otak dan herniasi. Pada subjek yang mengalami hiponatremia, diketahui $65,4 \%$ berjenis kelamin lakilaki dengan median umur 1 tahun. Seluruh subjek yang mengalami hiponatremia diketahui menerima cairan hipotonik pasca operasi dengan lama rawat

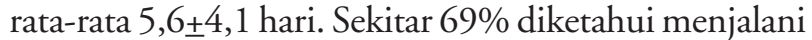
prosedur bedah laparatomi dengan natrium pre operasi berkisar $137 \mathrm{mEq} / \mathrm{L}$ (135-145) mEq/L. Rerata kadar natrium pasca operasi adalah $130,1 \pm 4,1 \mathrm{mEq} / \mathrm{L}$ dengan total cairan rata-rata $79,8 \pm 27,4 \mathrm{~mL} / \mathrm{kg}$.

Tabel 3. Insiden hiponatremia secara keseluruhan berdasarkan jenis cairan pasca operasi

\begin{tabular}{lccc}
\hline Hiponatremia & Ya $(\%)$ & Tidak $(\%)$ & Total $(\%)$ \\
\hline Jenis cairan & 0 & 6 & 6 \\
Isotonik & $(0 \%)$ & $(100 \%)$ & $(100 \%)$ \\
\multirow{3}{*}{ Hipotonik } & 26 & 58 & 84 \\
\multirow{2}{*}{ Total } & $(31 \%)$ & $(69 \%)$ & $(100 \%)$ \\
& 26 & 64 & 90 \\
\hline
\end{tabular}

$\mathrm{p}=0,12$

Tabel 4. Derajat hiponatremia berdasarkan jenis cairan pasca operasi

\begin{tabular}{|c|c|c|c|c|c|}
\hline \multirow{2}{*}{ Jenis cairan } & \multicolumn{4}{|c|}{ Frekuensi hiponatremia (\%) } & \multirow{2}{*}{ Total } \\
\hline & Tidak & Ringan & Sedang & Berat & \\
\hline Hipotonik & $58(69)$ & $16(19)$ & $8(9,5)$ & $2(2,5)$ & $84(100)$ \\
\hline Isotonik & $6(100)$ & $0(0)$ & $0(0)$ & $0(0)$ & $6(100)$ \\
\hline Total & $64(71,2)$ & $16(17,8)$ & $8(8,8)$ & $2(2,2)$ & $90(100)$ \\
\hline
\end{tabular}


Tabel 5. Komplikasi pada hiponatremia

\begin{tabular}{lccc}
\hline & Ya & Tidak & Persentase (\%) \\
\hline Edema otak & 0 & 26 & 0 \\
Herniasi & 0 & 26 & 0 \\
Kejang & 0 & 26 & 0 \\
Kejang dan edema otak & 1 & 25 & 3.8 \\
Mortalitas & 0 & 26 & 0 \\
\hline
\end{tabular}

\section{Pembahasan}

Kami mendapatkan perbandingan laki-laki dan perempuan $1,3: 1$, total subjek $65,4 \%$ yang mengalami hiponatremia adalah laki-laki. Pada studi kohort retrospektif di Washington DC didapatkan hasil yang sama, yaitu laki-laki menjadi mayoritas subjek mengalami hiponatremia $(1,2: 1)$, tetapi penyebab perbedaan kejadian hiponatremi pada anak laki-laki dan perempuan hingga saat ini belum diketahui. ${ }^{5}$

Kelompok usia terbanyak adalah 1 bulan 4 tahun dengan median usia yang mengalami hiponatremia pasca operasi adalah 2 tahun. Hal tersebut dimungkinkan karena pasien anak memiliki risiko lebih besar disebabkan oleh kapasitas sistem pompa $\mathrm{Na+-K+-ATPase} \mathrm{sel} \mathrm{otak} \mathrm{yang} \mathrm{terbatas.}$ Kelompok usia ini juga lebih mudah mengalami edema otak karena rasio kapasitas intrakranial terhadap ukuran otak yang besar, volume cairan serebrospinal yang kecil, serta kadar natrium intrasel anak yang 27\% lebih tinggi dibandingkan dewasa.

Hampir separuh subjek menjalani tindakan laparatomi $(47,8 \%)$ dengan berbagai indikasi, seperti reseksi tumor, transposisi kolon, adhesiolisis, prosedur Kasaii, eksisi kista, pemasangan kolostomi, hingga reseksi anastomosis. Durasi operasi subjek bervariasi dari 1 jam hingga 14,5 jam dengan median 4,5 jam. Sekitar 69\% subjek yang mengalami hiponatremia menjalani prosedur bedah abdomen (laparatomi). Operasi abdomen lebih berisiko meningkatkan sekresi (hipersekresi) ADH. Mekanisme belum diketahui, tetapi diduga diperantarai oleh aferen nyeri. ${ }^{21}$ Studi menunjukkan bahwa usia, merokok, dan nyeri adalah faktor yang dapat meningkatkan sekresi ADH. Nyeri melibatkan dua komponen, yaitu sensasi lokal yang diperantarai traktus spinotalamus dan rangsangan pada formatio retikularis, talamus ventral, dan hipotalamus. Stimulasi pada formatio retikularis di batang otak menunjukkan peningkatan $\mathrm{ADH}$ pada hewan. ${ }^{22,23}$ Pada penelitian kami, kualitas nyeri tidak dinilai.
Hampir semua $(93,3 \%)$ subjek mendapatkan cairan hipotonik pasca operasi. Hasil penelitian kami sesuai dengan studi kohort retrospektif di Children's National Medical Center yang juga mendapatkan sebagian besar subjek hiponatremia menerima cairan hipotonik pasca operasi (80\%), tetapi dengan jenis tindakan bedah yang bervariasi. ${ }^{5}$

Pada pengamatan selama subjek dirawat di ruang intensif, sebagian besar subjek dirawat selama kurang dari 5 hari dengan kuantitas 68,9\% (62 subjek). Pada subjek yang mengalami hiponatremia lama rawat bisa berlangsung hingga 20 hari dengan ratarata 5,6 64,1 hari dan meningkat pada subjek yang mengalami hiponatremia sedang dan berat $(8,8 \pm 1,7)$ hari. Sebuah penelitian kohort retrospektif yang melibatkan 27 rumah sakit di Amerika melaporkan bahwa hiponatremia meningkatkan lama perawatan, baik di ruang perawatan biasa maupun ruang rawat intensif. ${ }^{24}$ Terdapat empat subjek yang mengalami luaran mortalitas pada penelitian ini, tetapi tidak ada yang berkaitan dengan hiponatremia.

Hasil penelitian kami menunjukkan pemberian cairan perioperatif yang bervariasi, baik dari segi jenis maupun jumlahnya. Hal tersebut kemungkinan disebabkan belum terdapatnya pedoman pemberian terapi cairan di RSCM untuk menentukan jenis dan jumlah cairan perioperatif, masih bersifat individual. Hal serupa juga ditemukan di Inggris. Survei yang melibatkan 203 konsulen anestesi anak menunjukkan bahwa $67,7 \%$ dari sampel pada penelitian tersebut tidak memiliki kebijakan lokal mengenai peresepan cairan perioperatif. Cairan hipotonik intra operasi diresepkan $60,1 \%$ dan cairan hipotonik pasca operasi $75,2 \%$.

Angka kejadian hiponatremia pasca operasi secara keseluruhan cukup tinggi, yaitu 28,9\%, dengan insiden hiponatremia sedang 8,9\% dan hiponatremia berat 2,2\%. Seluruh kejadian hiponatremia terdapat pada kelompok yang mendapatkan cairan hipotonik, mayoritas subjek $(34,4 \%)$ berada pada kelompok yang mendapat dextrose 10\% 1/5 normal salin + $\mathrm{KCl}(10)$, diikuti dengan dextrose 3,75\% 1/4 normal salin 33,3\%. Tidak terdapat kejadian hiponatremia pada kelompok yang mendapatkan cairan isotonik ( $0 / 6$ subjek), tetapi perbedaan ini secara statistik tidak bermakna. Sebuah uji klinis yang melibatkan 122 pasien anak pasca bedah di PICU yang mengukur elektrolit darah saat 0,6, dan 24 jam sejak mendapatkan cairan pasca operasi melaporkan angka kejadian hiponatremia yang lebih 
besar pada pasien yang mendapat cairan hipotonik $(\mathrm{NaCl}<100 \mathrm{mEq} / \mathrm{L})$ dibandingkan kelompok isotonik, dengan number needed to harm sebesar $7 .{ }^{25}$ Studi kohort prospektif lain pada 81 pasien pasca bedah meneliti angka kejadian hiponatremia iatrogenik pada pasien yang mendapat cairan hipotonik $\left(\mathrm{Na}^{+} 40 \mathrm{mmol} / \mathrm{L}\right.$ dan $\mathrm{K}^{+} 20 \mathrm{mmol} / \mathrm{L}$ ) dengan jumlah sesuai perhitungan rumatan Holliday-Segar. Hasil penelitian tersebut menunjukkan insiden hiponatremia pada jam ke-12 pasca bedah adalah 21\%. ${ }^{1}$ Uji klinis pada 124 anak yang mendapatkan normal salin dan $1 / 2$ normal salin dengan laju rumatan $50 \%$ dan $100 \%$ menunjukkan bahwa risiko hiponatremia pada anak pasca operasi akan berkurang pada pemberian cairan isotonik dan bukan pada pemberian restriksi cairan. ${ }^{26}$ Pada penelitian kami, pasien yang mendapat kristaloid isotonik tidak ada yang mengalami hiponatremia, tetapi sayangnya jumlah subjek yang mendapat cairan pasca operasi kristaloid isotonik sangat sedikit, yaitu hanya 6 subjek.

Hasil serupa juga didapatkan pada suatu studi kohort yang dilakukan di Washington DC yang melaporkan insiden hiponatremia sedang 13,7\% dengan perincian kelompok hipotonik 10,3\% (12/116), dibandingkan dengan kelompok isotonik $3,4 \%(1 / 29)$. Sementara itu, hiponatremia berat terjadi pada 2,6\% (3/116) kasus yang terjadi hanya pada kelompok hipotonik. ${ }^{5}$

Sebuah studi meta-analisis pada tahun 2006 melaporkan bahwa cairan hipotonik meningkatkan kejadian hiponatremia akut secara bermakna dan meningkatkan morbiditas pasien. ${ }^{27}$ Pada penelitian kami memang tampak penurunan kadar natrium darah dari pemeriksaan pre operasi ke pemeriksaan pasca operasi (selisih 13,1 $\pm 5,8 \mathrm{mEq} / \mathrm{L}$ ) yang cukup bermakna secara klinis walaupun tidak bermakna secara statistik. Akan tetapi, masih banyak faktor lain yang berpengaruh terhadap kadar natrium darah di luar jenis dan jumlah cairan, seperti tingkat stres yang akan menentukan kadar $\mathrm{ADH}$ dalam tubuh serta asupan minuman atau makanan pada pasien yang sudah diperbolehkan mendapatkan diet enteral.

Penelitian kami sulit untuk memberikan rekomendasi regimen cairan pasca operasi yang ideal karena beberapa alasan. Kami tidak dapat menetapkan bahwa kejadian hiponatremia, baik secara keseluruhan, maupun sedang dan berat secara statistik disebabkan oleh penggunaan cairan hipotonik pasca operasi. Hal tersebut disebabkan distribusi yang asimetris antara regimen cairan yang diterima oleh subjek dan juga power penelitian yang rendah, yaitu hanya 0,08 untuk kejadian hiponatremia secara keseluruhan. Untuk mendapatkan power $80 \%$ dalam hal mendeteksi perbedaan antara insiden yang terjadi pada kedua kelompok, membutuhkan 150 jumlah subjek untuk masing-masing kelompok. Terdapat juga beberapa faktor yang memengaruhi terjadinya hiponatremia di luar faktor yang diamati, antara lain adalah respon stres. Pasca tindakan operasi mayor, terjadi respon stres yang ditandai dengan aktivasi sistem saraf simpatis dan peningkatan sekresi hormon hipofisis serta target organ. ${ }^{28}$

Masih terdapat perdebatan terkait regimen penggunaan cairan pasca operasi yang tepat. Terdapat sekitar 15.000 orang per tahun meninggal karena ensefalopati hiponatremia. ${ }^{29}$ Diperkirakan 8\% mortalitas terkait langsung terhadap ensefalopati hiponatremia pada anak dengan hiponatremia pasca operasi (didefinisikan sebagai kadar natrium serum $<129 \mathrm{mEq} / \mathrm{L}$ ), dan tata laksana cairan pasca operasi sebaiknya menggunakan cairan isotonik. Hal tersebut sejalan dengan 15 studi prospektif lain, melibatkan lebih dari 500 pasien, yang melaporkan bahwa penggunaan cairan isotonik dapat mencegah hiponatremia dan komplikasi yang terkait. ${ }^{30}$

Suatu studi kohort retrospektif melaporkan luaran yang buruk ditemui pada pasien yang memiliki penurunan kadar natrium selama perawatan di rumah sakit. Hiponatremia terkait dengan angka rawat di ruang perawatan intensif yang tinggi dan penggunaan ventilator pada 48 jam pertama perawatan dibandingkan terhadap pasien dengan kadar natrium yang normal (normonatremia). Ditemukan tingkat kematian selama perawatan yang juga meningkat. ${ }^{24}$ Penelitian lain melaporkan tingkat mortalitas pasien dengan hiponatremia tiga kali lipat lebih tinggi dibandingkan pasien normonatremia. ${ }^{31}$

Pada 26 kasus yang diidentifikasi hiponatremia pada penelitian kami didapatkan 1/26 subjek hiponatremia mengalami kejang dan edema otak. Subjek menjalani pengangkatan tumor clivus dengan dokter THT sebagai operator, lama operasi 5 jam 30 menit dengan kadar natrium praoperasi $142 \mathrm{mEq} / \mathrm{L}$ dan turun menjadi $123 \mathrm{meq} / \mathrm{L}$ pada 24 jam pertama pasca operasi. Cairan pasca operasi yang diberikan berupa $\mathrm{D}_{3,75} 1 / 4$ NS (96\% Holliday-Segar). Selama di ruang perawatan intensif, pasien menggunakan ventilator mekanik dan juga mendapatkan terapi manitol. Edema otak pada anak sudah dapat terjadi pada kadar natrium $120 \mathrm{mEq} / \mathrm{L}$, 
dibandingkan dengan dewasa $(111 \mathrm{mEq} / \mathrm{L})$, yang disebabkan berbagai faktor, seperti rasio kapasitas intrakranial terhadap ukuran otak yang besar, volume cairan serebrospinal yang kecil, kapasitas sistem pompa $\mathrm{Na}+\mathrm{K}+$-ATPase sel otak yang terbatas, serta kadar natrium intrasel otak yang lebih tinggi 27\% dibandingkan dewasa. ${ }^{32}$ Edema otak merupakan kondisi gawat darurat yang bila tidak dilakukan tata laksana dengan cepat dapat menyebabkan herniasi batang otak ke foramen magnum dan menyebabkan kerusakan otak permanen. Manifestasi klinis pada fase awal ditandai dengan mual, muntah, apatis, dan kelelahan. Fase lanjut ditandai dengan perubahan status mental, kejang, dan koma. Manifestasi sistemik, seperti hipoksia, edema pulmonal, dan kekakuan otot juga dapat terjadi. ${ }^{33}$ Tidak didapatkan subjek yang mengalami herniasi dan tidak didapatkan mortalitas yang berkaitan dengan hiponatremia. Kondisi ini mungkin terjadi karena evaluasi yang ketat di ruang intensif sehingga tata laksana hiponatremia dapat segera diberikan sebelum munculnya komplikasi.

\section{Kesimpulan}

Sebagian besar pasien mendapatkan cairan hipotonik dan hampir 30\% mengalami kejadian hiponatremia pasca tindakan operasi mayor di ruang perawatan intensif anak. Pemantauan kadar natrium pasca operasi secara berkala penting untuk mencegah komplikasi neurologis serius dan kematian. Penelitian lebih lanjut juga diperlukan untuk mengetahui cairan pascaoperasi yang paling tepat.

\section{Daftar pustaka}

1. Eulmesekian PG, Perez A, Minces PG, Bohn D. Hospital-acquired hyponatremia in postoperative pediatric patients: Prospective observational study. Pediatr Crit Care Med 2010;11:479-83.

2. Choong K, Arora S, Cheng J, Farrokhyar F, Reddy D, Thabane L, dkk. Hypotonic versus isotonic maintenance fluids after surgery for children: A randomized controlled trial. Pediatrics 2011;128:857-64.

3. Hughes PD, McNicol CD, Mutton PM, Flynn GJ, Tuck R, Yorke P. Postoperative hyponatraemic encephalopathy: Water intoxication. Aust NZ J Surg 1998;68:165-8.

4. Moritz ML, Ayus JC. Prevention of hospital-acquired hyponatremia: A case for using isotonic saline. Pediatrics 2003;111:227-30.

5. Au K, Ray PE, McBryde KD, Newman KD, Weinstein SL, Bell MJ. Incidence of postoperative hyponatremia and complications in critically-ill children treated with hypotonic and normotonic solutions. J Pediatr 2008;152:33-8.

6. Arieff AI. Postoperative hyponatraemic encephalopathy following elective surgery in children. Pediatr Anesth 1998;8:1-4.

7. Haycock GB. The syndrome of inappropriate secretion of antidiuretic hormone. Pediatr Nephrol 1995;9:37581 .

8. Judd BA, Haycock GB, Dalton RN, Chantler C. Antidiuretic hormone following surgery in children. Acta Paediatr Scand 1990;79:461-6.

9. Pillai BP, Unnikrishnan AG, Pavithran PV. Syndrome of inappropriate hormone secretion: revisiting a classical endocrine disorder. Indian J Endocrinol Metb 2011;15:S208-15.

10. Leffen R, Chawls W. Fluid and electrolyte management. Dalam: Oldham K, Colombani P, Foglia R, penyunting. Surgery of Infants and children. Edisi ke-2. Philadelphia: Lippincot-Raven; 1997. h.83-115.

11. Lee JM, Jung Y, Lee SE, Lee JH, Kim KH, Koo JW, dkk. Intravenous fluid prescription practices among pediatric residents in Korea. Korean J Pediatr 2013;56:282.

12. Way C. Perioperative fluid therapy in children: a survey of current prescribing practice. Brit J Anaesth 2006;97:371-9.

13. Freeman MA, Ayus JC, Moritz ML. Maintenance intravenous fluid prescribing practices among paediatric residents. Acta Paediatr 2012;101:e465-8.

14. Cavari Y, Pitfield AF, Kissoon N. Intravenous maintenance fluids revisited. Pediatr Emerg Care 2013;29:1225-8.

15. Moritz ML, Ayus JC. Intravenous fluid management for the acutely ill child. Curr Opin Pediatr 2011;23:18693.

16. Moritz ML, Ayus JC. New aspects in the pathogenesis, prevention, and treatment of hyponatremic encephalopathy in children. Pediatr Nephrol 2009;25:1225-38.

17. Lander A. Paediatric fluid and electrolyte therapy guidelines. Surgery 2010;28:369-72.

18. Choong K, Bohn D. Maintenance parenteral fluids in the critically ill child. J Pediatr 2007;83:3-10.

19. Holliday MA, Friedman AL, Segar WE, Chesney R, Finberg L. Acute hospital-induced hyponatremia in children: a physiologic approach. J Pediatr 2004;145: 584-7. 
20. Holliday MA, Segar WE, Friedman A. Reducing errors in fluid therapy management. Pediatrics 2003;111:22730.

21. Fieldman NR, Forsling ML, Le Quesne LP. The effect of vasopressin on solute and water excretion during and after surgical operations. Ann Surg 1985;201:383-90.

22. Kendler KS, Weitzman RE, Fisher DA. The effect of pain on plasma arginine vasopressin concentrations in man. Clin Endocrinol 1978;8:89-94.

23. Szczenpanska-Sadowska E, Simon-Oppermann C, Gray D, Simon E. Control of central release of vasopressin. J Physiol 1984;79:432-9.

24. Zilberberg MD, Exuzides A, Spalding J, Foreman A, Jones AG, Colby C, dkk. Hyponatremia and hospital outcomes among patients with pneumonia: a retrospective cohort study. BMC Pulm Med 2008;8:16.

25. Montañana PA, Modesto i Alapont V, Ocón AP. The use of isotonik fluid as maintenance therapy prevents iatrogenic hyponatremia in pediatrics: A randomized, controlled open study. Pediatr Crit Care Med 2008;9:589-97.

26. Neville KA, Sanderman DJ, Rubinstein A, Henry GM, McGlynn M, Walker JL. Prevention of hyponatremia during maintenance intravenous fluid administration: a prospective randomized study of fluid type versus fluid rate. J Pediatr 2010;156:313-9.
27. Choong K, Kho ME, Menon K, Bohn D. Hypotonic versus isotonic saline in hospitalized children: A systemic review. Arch Dis Child 2006;91:828-35.

28. Dimopoulou I, Tzanela M, Vassiliadi D, Mavrou I, Kopterides P, Orfanos S, dkk. Pituitary-adrenal responses following major abdominal surgery. Hormones. 2008;7:237-42.

29. Ayus JC, Arieff AI. Brain damage and postoperative hyponatremia: the role of gender. Neurology 1996;46: 323-8.

30. Moritz ML, Ayus JC. Preventing neurological complications from dysnatremias in children. Pediatr Nephrol 2005;20:1687-700.

31. Gill G, Huda B, Boyd A, Skagen K, Wile D, Watson I, dkk. Characteristics and mortality of severe hyponatremia - a hospital-based study.Clin Endocrinol (Oxf) 2006;65:246-9.

32. Bailey AG, McNaull PP, Jooste E, Tuchman JB. Perioperative crystalloid and colloid fluid management in children: Where are we and how did we get here? Paediatr Anaesth 2010;110:375-90.

33. Carpenter J, Weinstein S, Myseros J, Vezina G, Bell MJ. Inadvertent hyponatremia leading to acute cerebral edema and early evidence of herniation. Neurocrit Care 2007;6:195-9. 